\title{
Start-Up Raising: Web Development Company Based on Coffee Industry
}

\author{
Amanna D. Al Hakim ${ }^{1}$, "Pathmi Noerhatini², Aditya K. Siahaan ${ }^{3}$, Raka M. \\ Azka $^{4}$, Siti K. Azhari ${ }^{5}$, Dicky R.Munaf ${ }^{6}$
}

${ }^{1}$ Nusa Putra University, Sukabumi, Indonesia.

${ }^{2}$ Humanity Research Group, Faculty of Art and Design, ITB, Bandung, Indonesia

${ }^{3}$ Humanity Research Group, Faculty of Art and Design, ITB, Bandung, Indonesia

${ }^{4}$ Humanity Research Group, Faculty of Art and Design, ITB, Bandung, Indonesia

${ }^{5}$ Humanity Research Group, Faculty of Art and Design, ITB, Bandung, Indonesia

${ }^{6}$ Humanity Research Group, Faculty of Art and Design, ITB, Bandung, Indonesia

*Corresponding author. Email: pathmi@fsrd.itb.ac.id

\begin{abstract}
Arabica Web Solutions is a web development of start-up company that focuses on the coffee industry. The writers chose to establish the start-up because of the advancement of technology and the digitalization of businesses in the modern era which plays a crucial role when it comes to marketing. By seeking through Arabica Web Solution's business qualification record and potential, Arabica Web Solutions have surfaced to be a worthwhile start-up company to raise. For this reason, the authors wish Arabica Web Solutions to have an impactful future in the web development industry as well as the coffee industry.
\end{abstract}

Keywords: Start-Up, Arabica Web Solutions, Web Development, Coffee industry.

\section{INTRODUCTION}

A start-up is an organization designed to find a suitable business model to generate rapid development [1]. Start-ups in Indonesia are ranked sixth with 1,939 start-ups, and based on predictions about the number of digital-based start-ups that will appear in 2020 in Indonesia, and there are as many as 13,000 start-ups [2]. This increase in the number of start-ups is also due to support from the government, for example, by forming the National 1,000 Start-Up Movement through the Ministry of Communication and Information in collaboration with a company to build a digital ecosystem in Indonesia called KIBAR, explicitly aiming to realize Indonesia's potential to become The Digital Energy of Asia in 2020 by printing 1,000 start-ups that will be solutions to various problems by utilizing digital technology [3].

One of the start-ups is Arabica Web Solutions, which is a web development of start-up company that focuses on the coffee industry.
Arabica Web Solutions specializes in producing data-driven websites that create web designs that uncover the true coffee business identity and what you offer to coffee connoisseurs.

Based on the growing digital marketing [5], the Arabica Web Solution formation is intended for the coffee industry, including coffee shops, roasters, distributors, farmers, etc. These companies would proceed with multiple benefits such as marketing, a boost in sales, analytics for future predictions, and many more.

This start-up has made business predictions for three years, namely 2021, 2022, and 2023. To determine the feasibility of this start-up, we will analyze it using several indicators, including the payback period and NPV (Net Present Value). We will also analyze profit using BEP (Break-even point) analysis. 


\section{BUSINESS DESCRIPTION}

\subsection{Vision, Mission, and Objectives}

Our vision is to help coffee businesses grow and expand through digital marketing. Our Mission is to provide accessible and streamlined web services to the coffee business, offering responsive, appealing, and secure web service by technology experts and giving the best service to clients. Our business aims to allow customers to visualize their image on their websites and give high-quality web development services for customers.

\subsection{From a Business Idea to the Business Description}

Arabica Web Solutions is a business idea of which it offers web development services to coffee businesses. The business services include web design in which content marketing and development is carried out. These e-commerce services focus on digital marketing, data analysis, marketing automation, and website securing and hosting. The company utilizes Cloud to perform its services securely and wellorganized through an integrated system. This business aims to help small coffee businesses such as local coffee shops boost their sales through digital marketing; a simple way to elaborate this is that these companies will be seen more in online advertisement. That way, these small-scale businesses would expand their market and can keep up with the modern trend [6]. In addition, Arabica Web Solutions' data-driven basis would also help these companies explore new opportunities in the coffee industry sector.

The company is run by experts with a software development background, in which there are three permanent directors, and the best developers from across Indonesia are hired through contract work. The company projects its promotion to be done through online platforms such as social media and other professional services such as LinkedIn and Upwork. Since the company uses Cloud and an online system, it is run remotely for its initial years.

\section{MARKETING ASPECT}

\subsection{Market Segment, Target Market, and Positioning}

\subsubsection{Segmentation}

\section{1) Geographic}

Arabica Web Solutions operates as an online business where most of its work is done remotely. The business has yet to have a wide variety of clients; therefore, the company is focusing on Bandung's coffee shop and roasting business market.

\section{2) Demographic}

Technically, Arabica Web Solutions offers its services to all levels of the coffee business, however, as of now, we are focusing on small market coffee businesses that need digital marketing.

\section{3) Psychographic}

Arabica Web Solutions suits best for small coffee companies that have become successful in their local market and in seek of aid for an affordable web agency that would boost their marketing.

\subsubsection{Targeting}

The target market for Arabica Web Solutions is mainly for small coffee business that has become successful in their local market and in seeks of aid for an affordable web agency that would boost their marketing.

\subsubsection{Positioning}

Arabica Web Solutions aims to produce the best quality services in building web solutions for clients compared to other companies. We put customer's visualization of the website and integrate with our high-quality design and security to build the web system.

\subsection{Supply and Demand Forecast}

\subsubsection{Estimated Demand}

There is a spike increase in coffee trends around Bandung in this era. This does not only specify coffee shops but also coffee roasters and coffee processing companies in which the upgoing trend is in seek of continuous marketing along the way. Therefore, when it comes to providing a good website that offers design and interactive features, mobile innovation, and optimum security, we would ensure that clients would be grateful for our web services. The table below shows the Demand Forecast.

Table 1. Demand Forecast

\begin{tabular}{|c|c|}
\hline Year & Demand (Client service) \\
\hline 2021 & 150 \\
\hline 2022 & 200 \\
\hline 2023 & 270 \\
\hline
\end{tabular}

\subsubsection{Supply Forecast}


Since Arabica Web Solutions is a company that offers services as its products, there is no supply of raw materials/input products. All the frameworks, including front-end and backend, are all on the internet, mostly are open-source, and these raw frameworks depend on the client's demands for the website they wish to be.

\subsection{Sales Plan and Market Share}

The market opportunities of Arabica Web Solutions can be calculated from the potential demand subtracted by the amount of estimated supply. On the other hand, the market share can be calculated by the sales plan divided by its market opportunity.

Table 2. Sales Plan

\begin{tabular}{|c|c|c|c|c|c|}
\hline Year & $\begin{array}{c}\text { Potential } \\
\text { Demand }\end{array}$ & $\begin{array}{c}\text { Estimated } \\
\text { Supply }\end{array}$ & $\begin{array}{c}\text { Market } \\
\text { Opportunity }\end{array}$ & $\begin{array}{c}\text { Sales } \\
\text { Plan }\end{array}$ & $\begin{array}{c}\text { Market } \\
\text { Share }\end{array}$ \\
\hline 2021 & 150 & 15 & 135 & 8 & $7.4 \%$ \\
\hline 2022 & 200 & 25 & 175 & 15 & $8.5 \%$ \\
\hline 2023 & 270 & 45 & 235 & 25 & $10.6 \%$ \\
\hline
\end{tabular}

\subsection{Marketing Strategy Against Competitors}

Philip Kotler defines a marketing mix as a set of controlled marketing variables used by a company to generate company-controlled responses, from its target market, the marketing mix consists of everything a company can do to influence the demand for its products, known as the "four P's," namely product, price, location, and promotion [7].

\subsubsection{Product}

The services that Arabica Web Solutions offer differ from the competitors since our company integrates design mainly using Gatsby and the latest Bootstrap Front-End Framework with the best secure back-end framework Django, ensuring that all fullstack website aspects are top quality and to the customer's desires.

1) $\operatorname{Logo}$

A company's logo signifies the company's identity. An eye-catching logo would ignite consumers' emotions towards the company.

\section{AraBica weB SOLU[IOnS}

Figure 1. The Arabica Web Solutions Logo.

2) Price

The price of Arabica Web Solutions is based on three different categories, namely basic web design, intermediate and advanced with advanced offering the most features while still in the competitive market price. The higher the category of web design choice, the more benefit client get, such as size, better responsive features, more add-ons, e-commerce functionality benefits, better hosting service, more custom features, SEO service increases, database integration, and many more. Nevertheless, these categories all provide the best content marketing strategy for their websites.

\subsubsection{Promotion}

Arabica Web Solutions uses an online platform to promote its services, mainly through social media such as Instagram, Twitter, and Facebook. Other online platforms include professional sites such as Upwork Inc., LinkedIn, and Glassdoor.

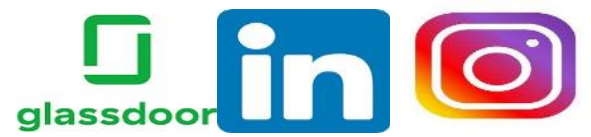

Figure 2. Online Platforms

\subsection{SWOT}

SWOT analysis, a commonly used tool for strategic planning, is traditionally a form of brainstorming. [8]

Table 3. SWOT Analysis

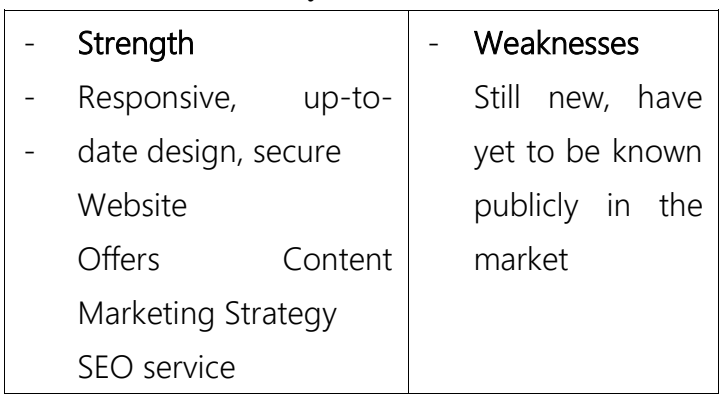




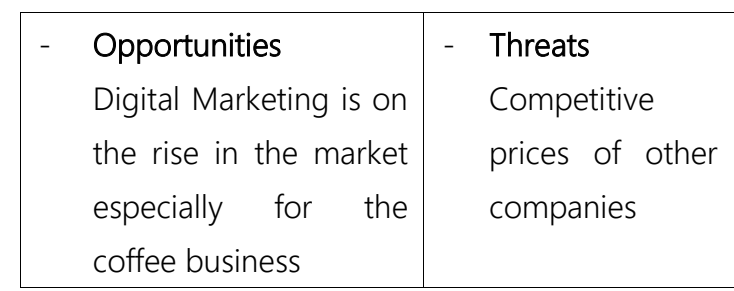

\section{ORGANIZATION AND MANAGEMENT ASPECTS}

\subsection{Human Resource and Organization}

Name of Business

Name of owner

Address of Business

Legal Entity

Organizational Structure:

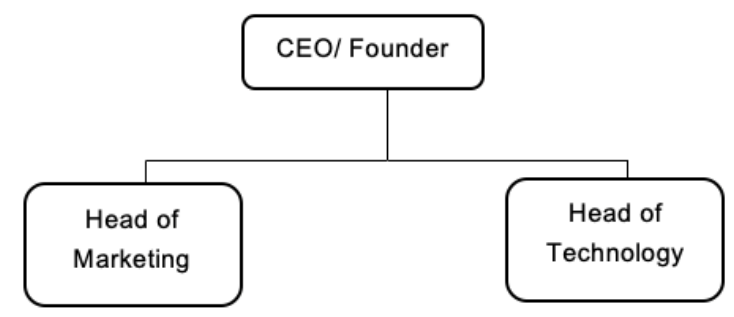

Figure 3. Organizational Structure of Arabica Web Solution

\subsection{Licensing}

Arabica Web Solutions is a private company that will register Surat Izin Usaha Perdagangan (SIUP). On the other hand, in the beginning, the steps of this business, Surat Ijin Tempat Usaha (SITU), are not needed. If Arabica Web Solutions expands its market in the future, a permanent office would be a requirement.

\subsection{Pre-Operation Activities and Implementation Schedule}

Table 4. Schedule

\begin{tabular}{|c|c|c|}
\hline No & Schedule & Activity \\
\hline 1 & 1st Month & $\begin{array}{l}\text { - } \text { Research and Development } \\
\text { - Cost Structure and } \\
\text { Financial Planning }\end{array}$ \\
\hline 2 & $2^{\text {nd }}$ Month & $\begin{array}{ll}\text { - } & \text { Establishing Key partners } \\
\text { - } & \text { Training workforce } \\
\text { - } & \text { Finding potential Clients }\end{array}$ \\
\hline 3 & $3^{\text {rd }}$ Month & $\begin{array}{l}\text { - Start with the small client, } \\
\text { charging at low category }\end{array}$ \\
\hline
\end{tabular}

\begin{tabular}{|c|c|c|}
\hline & & - $\quad$ Start advertising \\
\hline \multirow{2}{*}{4} & \multirow{2}{*}{$4^{\text {th }}$ Month } & $\begin{array}{ll}\text { - } & \text { Market evaluation } \\
\text { - } & \text { Resource Improvements }\end{array}$ \\
\hline & & $\begin{array}{l}\text { - Marketing through more } \\
\text { designated platforms }\end{array}$ \\
\hline 5 & $5^{\text {th }}$ Month & $\begin{array}{ll}\text { - } & \text { Market evaluation } \\
\text { - } & \text { Determine with key } \\
& \text { partners } \\
\text { - } & \text { R\&D improvements } \\
\text { - } & \text { Big-Scale Marketing }\end{array}$ \\
\hline 6 & $6^{\text {th }}$ Month & $\begin{array}{l}\text { - } \quad \text { Launching } \\
\text { - } \quad \text { Continue with Marketing }\end{array}$ \\
\hline
\end{tabular}

\section{FINANCIAL ASPECT}

\subsection{Funding Sources}

To initiate the company's operations, there needs to be capital to provide funding from the start. For Arabica Web Solutions, capital is prepared from the founder's freelancing income for approximately $\mathrm{Rp}$. $50,000,000$. The initial funding should cover costs such as high-speed internet, compatible laptop, computer monitor, marketing, research and development, and operational costs.

\subsection{Investment Capital}

The investment capital for Arabica Web Solutions for the 1 st year is approximate $\mathrm{Rp}$. $40,000,000$. This amount is used to buy paid web frameworks, pay the first contract web developers, additional equipment, and back-up internet. Advertisement costs could go up to Rp. 4,000,000.

\subsection{Business Feasibility Analysis}

Business feasibility analysis is required to measure the value of money or the rate of return of the investment invested in the business in the future. A few variables have to be calculated which include, the payback period (PP), net present value (NPV), and internal rate of return (IRR).

\subsubsection{Payback Period}

The payback period is a method used to calculate the length of the period required to return the money invested from the annual cash inflow generated by the investment project [9]. 


$$
\text { - } P P=\frac{\text { Initial Investment }}{\text { Cash Inflows }}
$$

- Initial Investment = Rp. 50,000,000

- Cash inflow year 1 = Rp. 40,000,000 Hence,

$P P=\underline{\operatorname{Rp} 50,000,000} \times 1$ year $=1$ year 5 months $\operatorname{Rp} 40,000,000$

Thus, based on the calculation above, the payback period for Arabica Web Solution is around 1 year and 5

\subsubsection{Net Present Value}

Below is the net present value calculation using a discount rate with a rate of BI of $6.75 \%$ per month (Bank Indonesia, 2016) months.

$N P V=$ net cash $1+$ net cash $2+$ net cash $3-$ Investment $(1+\mathrm{r})(1+r)^{2}(1+r) 3$

Where: $r=$ return rate

$$
\begin{aligned}
\mathrm{NPV}=\frac{40.000 .000}{1+0.0675} & +\frac{50.000 .000}{(1+0.0675)^{2}} \\
& +\frac{60.000 .000}{(1+0.0675)^{3}}-50.000 .000
\end{aligned}
$$

$N P V=80.670 .240$

From the calculation above, the NPV value is Rp. $80,670,240$. This result shows a positive value, in which it concludes that the business is profitable and can operate soon.

\subsection{Profit Analysis}

Break-Even Point (BEP) is a tool to analyze the projection of how many units will be produced or how much money must be received to get a break-even point or return of capital. The following is the calculation of BEP:

- Year 2021:

BEP of Arabica Web Solutions in terms of clients

$$
\begin{aligned}
& \mathrm{BEP}=\frac{\text { fixed Cost }}{\text { Selling price }- \text { variable cost }} \\
& \mathrm{BEP}=\frac{50.000 .000}{5.000 .000-1.500 .000} \\
& B E P=1.429 \text { Client }
\end{aligned}
$$

BEP of Arabica Web Solutions in terms of Rupiah

$$
\mathrm{BEP}=\frac{\text { Fixed cost }}{1-(\text { Variable cost } / \text { Selling price }}
$$

$\mathrm{BEP}=\frac{50.000 .000}{1-(1.500 .000 / 5.000 .000}$

$B E P=R p .71 .428 .571$

Therefore, to reach BEP of 2021, Arabica web solutions in terms of clients again must serve at least 2 clients or the sales equivalent of $R p 71.428 .571$ that years.

\section{- Year 2022}

BEP of Arabica Web Solutions in terms of clients

$\mathrm{BEP}=\frac{\text { fixed Cost }}{\text { Selling price }- \text { variable cost }}$

$\mathrm{BEP}=\frac{55.000 .000}{5.500 .000-1.500 .000}$

$B E P=1.375$ Client

BEP of Arabica Web Solutions in terms of Rupiah:

$$
\begin{aligned}
\mathrm{BEP} & =\frac{\text { Fixed cost }}{1-(\text { Variable cost } / \text { Selling price }} \\
\mathrm{BEP} & =\frac{55.000 .000}{1-(1.500 .000 / 5.500 .000} \\
B E P & =R p .75 .625 .000
\end{aligned}
$$

Therefore, to reach the BEP of 2022, Arabica Web Solutions again must serve at least 2 clients or the sales equivalent of $R p .75,625,000$ that year.

\section{- Year 2023}

BEP of Arabica Web Solutions in terms of clients:

$$
\begin{aligned}
& \mathrm{BEP}=\frac{\text { fixed Cost }}{\text { Selling price }- \text { variable cost }} \\
& \mathrm{BEP}=\frac{60.000 .000}{60.00 .000-1.500 .000} \\
& B E P=1.333 \text { Client }
\end{aligned}
$$

BEP of Arabica Web Solutions in terms of Rupiah:

$$
\begin{aligned}
& \mathrm{BEP}=\frac{\text { Fixed cost }}{1-(\text { Variable cost } / \text { Selling price }} \\
& \mathrm{BEP}=\frac{60.000 .000}{1-(1.500 .000 / 6000.000} \\
& B E P=R p .80 .000 .000
\end{aligned}
$$

Therefore, to reach BEP of 2023, Arabica Web Solutions again must serve at least 2 clients or the sales equivalent of $R p .80,000,000$ that year. 


\subsection{Financial Report}

Financial statements are reports that display the financial condition of a company containing a balance sheet, income statement, and other reports. The table below shows an estimation of the Financial Report of Arabica Web Solutions (in Rupiahs).

Table 5. Financial Report

\begin{tabular}{|c|c|c|c|}
\hline Details & $2021(\mathrm{Rp})$ & $2022(\mathrm{Rp})$ & $2023(\mathrm{Rp})$ \\
\hline Revenue & $100,000,000$ & $120,000,000$ & $140,000,000$ \\
\hline HPP & $30,000,000$ & $33,000,000$ & $36,000,000$ \\
\hline Operation Gross Profit & $130,000,000$ & $153,000,000$ & $176,000,000$ \\
\hline Salary Expenses & $40,000,000$ & $43,000,000$ & $46,000,000$ \\
\hline Additional Expenses & $10,000,000$ & $13,000,000$ & $15,000,000$ \\
\hline Depreciation & $3,000,000$ & $3,000,000$ & $3,000,000$ \\
\hline Equipment \& Internet & $2,000,000$ & $2,200,000$ & $2,400,000$ \\
\hline Total Load & $55,000,000$ & $61,200,000$ & $66,400,000$ \\
\hline Gross Profit & $75,000,000$ & $91,800,000$ & $109,600,000$ \\
\hline Shrinkage & $3,000,000$ & $3,000,000$ & $3,000,000$ \\
\hline EBT & $72,000,000$ & $88,800,000$ & $106,600,000$ \\
\hline Tax (15\%) & $10,800,000$ & $13,320,000$ & $15,990,000$ \\
\hline EAT for 1 year & $61,200,000$ & $75,480,000$ & $90,610,000$ \\
\hline & & & \\
\hline
\end{tabular}

\section{CONCLUSION}

Arabica Web Solutions is a business idea of which it offers web development services to coffee businesses. A business idea is an initial stage of starting a start-up, which is implemented with the creation of a business plan. Based on our analysis, this business idea can continue to be a digital-based startup.

\section{ACKNOWLEDGMENTS}

We would like to thank LPPM ITB. Thanks, are also conveyed to Aditya K, Siahaan for the development of business ideas towards the formation of start-ups.

\section{REFERENCES}

[1] B. Rahardjo, $S$ ta $r$ ti n g u p. PT Insan Infonesia, 2017.

[2] E. Ries, The Lean Startup: How constant innovation creates radically successful businesses. Currency, 2011.

[3] R. Hardiansyah and D. Tricahyono, "Identifikasi Faktor-Faktor Kesuksesan Start Up Digital di Kota Bandung," J. Ekon., vol. 27, no. 2, pp. 134-145, 2019, [Online]. Available:

https://je.ejournal.unri.ac.id/index.php/JE/arti cle/view/7900/6807. 
[4] B. Lynne Milgram, "Social entrepreneurship and Arabica coffee production in the Northern Philippines: Navigating opportunities and constraints," Hum. Organ., vol. 80, no. 1, pp. 72-82, 2021, doi: 10.17730/1938-352580.1.72.

[5] C. Krishnan, M. Majid Baba, G. Singh, and J. Mariappan, Viral Marketing: A New Horizon and Emerging Challenges, vol. 246. 2022.

[6] P. C. Permatasari, A. Basith, and H. Mulyati, "Arabica Coffee Value Chain Inclusive Business Model in Bondowoso, East Java," $J$. Manaj. Teknol., vol. 17, no. 2, pp. 111-125, 2017, [Online]. Available: https://media.neliti.com/media/publications/2 60915-none-a6e4edf5.pdf.

[7] P. Kotler and K. L. Keller, "Manajemen pemasaran edisi kedua belas jilid 1," Penerbit PT. Indeks. Jakarta, 2012.

[8] B. Phadermrod, R. M. Crowder, and G. B. Wills, "Importance-Performance Analysis based SWOT analysis," Int. J. Inf. Manage., vol. 44, 2019, doi: 10.1016/j.ijinfomgt.2016.03.009.
[9] R. A. Purnomo, Riawan, and L. O. Sugianto, Studi Kelayan Bisnis. Ponorogo: Unmuh Ponorogo Press, 2017. 